\title{
PENGARUH MODEL PEMBELAJARAN BERBASIS MASALAH DENGAN METODE EKSPERIMEN PADA MATERI CAHAYA TERHADAP HASIL BELAJAR FISIKA SISWA KELAS VIII SMPN 2 GUNUNGSARI TAHUN AJARAN 2014/2015
}

\author{
Ardian Firmansyah ${ }^{1}$, Kosim $^{2}$, Syahrial Ayub ${ }^{2}$ \\ 1) Program Studi Pendidika Fisika \\ 2) Program Studi Pendidika Fisika FKIP \\ Universitas Mataram \\ Mataram, Indonesia \\ Email: ardianfirmansyah667@gmail.com
}

\begin{abstract}
The purpose of this study was to determine the effect of problem based learning model with experiment method of the topic light on student's physics learning outcomes of SMPN 2 Gunungsari academic year 2014/2015. The design of this study used experimental research with pretest-posttest control group design. The population of this study is students of grade VIII SMPN 2 Gunungsari, with sampling was using cluster random sampling technique. The samples are the students of class VIII A as experimental class and class VIII B as control class. Data results studying by test used is polled variance t-test. The results of the analysis of hypothesis test obtained $t_{\text {count }}=2,71$ compared with $t_{\text {table }}=2, .02$ at the significance level of 5\%. According to criteria of hypothesis testing, if $t_{\text {count }}>t_{\text {table }}$, then Ho is rejected and Ha accepted. It can be concluded that there are effect of problem based learning model with experiment method of the topic light on student's physics learning outcomes of SMPN 2 Gunungsari academic year 2014/2015.
\end{abstract}

Keywords: Problem Based Learning Model, Experimental Method, Learning Outcome

\section{Pendahuluan}

Sains adalah salah satu cabang ilmu pengetahuan yang terdiri dari fakta, konsep, prinsip, hukum dan teori dalam membahas fenomena alam khususnya di bidang fisika. Hakikat sains dipandang sebagai proses, produk, dan prosedur. Sebagai proses, sains diartikan sebagai kegiatan ilmiah unuk menyempurnakan pengetahuan mengenai alam maupun menemukan pengetahuan baru. Sebagai produk diartikan sebagai hasil proses berupa pengetahuan yang diajarkan dalam/luar sekolah maupun sebagai bahan bacaan untuk dissiminasi atau penyebaran pengetahuan. Sebagai prosedur diartikan sebagai metodologi atau cara yang dipakai untuk mengetahui sesuatu (riset pada umumnya) yang biasa disebut metode ilmiah [1].

Secara garis besar bahwa sains bukan hanya merupakan kumpulan pengetahuan berupa fakta, konsep, dan teori semata melainkan suatu proses penemuan. Sehingga dalam proses pembelajaran harus mempertimbangkan metode pembelajaran yang efektif dan efisien yaitu salah satunya kegiatan eksperimen. Proses pembelajaran yang menekankan pada pemberian pengalaman langsung yang menjadi wahana bagi siswa untuk mengembangkan dan memahami alam sekitar secara ilmiah. Kegiatan eksperimen pula memiliki peran motivasi dalam belajar, memberi kesempatan bagi siswa untuk mengembangkan sejumlah keterampilan dan meningkatkan kualitas belajar siswa.

Namun kenyataannya, selama kegiatan observasi yang peneliti lakukan di SMPN 2 Gunungsari, proses pembelajaran masih didominasi oleh guru (teacher center) dan jarang diadakan kegiatan eksperimen. Proses pembelajaran yang cenderung membuat siswa menerima apa saja materi yang disampaikan oleh guru tanpa mengetahui makna apa yang mereka pelajari. Siswa lebih banyak menghafal konsep dan rumus fisika, sehingga siswa terkadang kesulitan mengerjakan soal-soal latihan dan kurang memahami konsep yang telah dijelaskan oleh guru. Siswa juga kurang terlibat secara aktif dalam proses 
pembelajaran karena kurangnya kegiatan eksperimen yang dilakukan pada proses pembelajaran. Hal tersebut berdampak pada hasil belajar fisika siswa yang rendah.

Berdasarkan penjelasan diatas, maka upaya mengatasi permasalahan pembelajaran tersebut diperlukan suatu inovasi model pembelajaran. Salah satu model pembelajaran menurut peneliti yang memberikan peluang siswa dalam memahami konsep fisika adalah model pembelajaran berbasis masalah. Model pembelajaran berbasis masalah yang menyediakan pengalaman autentik yang mendorong siswa untuk belajar aktif, mengkonstruksi pengetahuan, dan mengintegrasi konteks belajar di sekolah dan belajar di kehidupan nyata secara ilmiah [2].

Pembelajaran berbasis masalah diartikan pula sebagai rangkaian kegiatan yang menekankan pada proses penyelesaian masalah secara ilmiah [3]. Pembelajaran yang lebih menitikberatkan dengan kegiatan eksperimen yang harus dilakukan siswa. Siswa tidak hanya sekedar mendengarkan, mencatat, dan menghafal materi yang disampaikan oleh guru, tetapi siswa diharapkan mampu berfikir, mencari, mengolah data, dan berkomunikasi dalam proses pembelajaran. Sehingga konsep atau materi yang didapat siswa terarah dan siswa terlibat secara aktif dalam proses pembelajaran yang mempermudahnya dalam menerima pelajaran.

Berdasarkan uraian diatas maka peneliti tertarik melakukan penelitian dengan judul "Pengaruh Model Pembelajaran Berbasis Masalah Dengan Metode Eksperimen Pada Materi Cahaya Terhadap Hasil Belajar Fisika Siswa Kelas VIII SMPN 2 Gunungsari Tahun Ajaran 2014/2015".

Sesuai dengan permasalahan yang telah dirumuskan di atas, maka tujuan penelitian ini adalah untuk mengetahui pengaruh model pembelajaran berbasis masalah dengan metode eksperimen pada materi cahaya terhadap hasil belajar fisika siswa kelas VIII SMPN 2 Gunungsari tahun ajaran 2014/2015. Hasil penelitian ini diharapkan bermanfaat bagi pengembangan model pembelajaran dalam mata pelajaran IPA fisika serta dapat bermanfaat bagi siswa, guru, peneliti, pembaca serta lembaga pendidikan tenaga keguruan yang ingin mengambil kajian yang sama guna meningkatkan hasil belajar fisika siswa.

\section{Metode Penelitian}

Jenis penelitian ini adalah penelitian eksperimen, yang merupakan metode penelitian yang digunakan untuk mencari pengaruh perlakuan tertentu terhadap variabel-variabel yang diteliti dan dalam kondisi yang dikendalikan [4]. Penelitian ini dilaksanakan mulai bulan November 2014 sampai dengan Juni 2015, bertempat di SMP Negeri 2 Gunungsari. Pada penelitian ini melibatkan tiga variabel utama yang menjadi fokus penelitian yaitu variabel bebas, variabel kontrol, dan variabel terikat. Variabel bebas pada penelitian ini adalah model pembelajaran berbasis masalah dengan metode ekperimen, variabel terikat adalah hasil belajar fisika siswa, dan variabel kontrol adalah materi pembelajaran, tujuan pembelajaran, silabus, RPP, LKS, cara penilaian dan jumlah jam pelajaran. Desain penelitian menggunakan pretest-posttest control group design yang bertujuan untuk memperoleh perbedaan hasil belajar fisika siswa antara kelas eksperimen dan kontrol, sehingga pada akhirnya akan mendapatkan pengaruh dari model pembelajaran yang digunakan. Secara bagan, desain penelitian ini digambarkan pada Tabel 1.

Tabel 1. Desain Penelitian Pretest-Posttest Control Group Design

\begin{tabular}{lccc}
\hline Kelompok & Pretest & Perlakuan & Posttest \\
\hline Eksperimen & $\mathrm{O}_{1}$ & $\mathrm{X}$ & $\mathrm{O}_{2}$ \\
Kontrol & $\mathrm{O}_{1}$ & - & $\mathrm{O}_{2}$ \\
\hline
\end{tabular}

(Diadaptasi dari: Sugiyono, 2014)

Adapun teknik pengambilan sampel yang digunakan adalah cluster random sampling. Melalui cluster random sampling didapatkan dua kelas yang terpilih secara acak. Sampel hasil yang didapatkan adalah kelas VIII-A dengan jumlah 21 orang sebagai kelas eksperimen dan siswa kelas VIII-B dengan jumlah 22 orang sebagai kelas kontrol.

Prosedur kegiatan penelitan ini dilakukan dalam tiga tahap, yaitu tahap persiapan, tahap pelaksanaan dan tahap akhir. Prosedur penelitian secara rinci dapat dilihat pada Bagan 1 dibawah ini: 


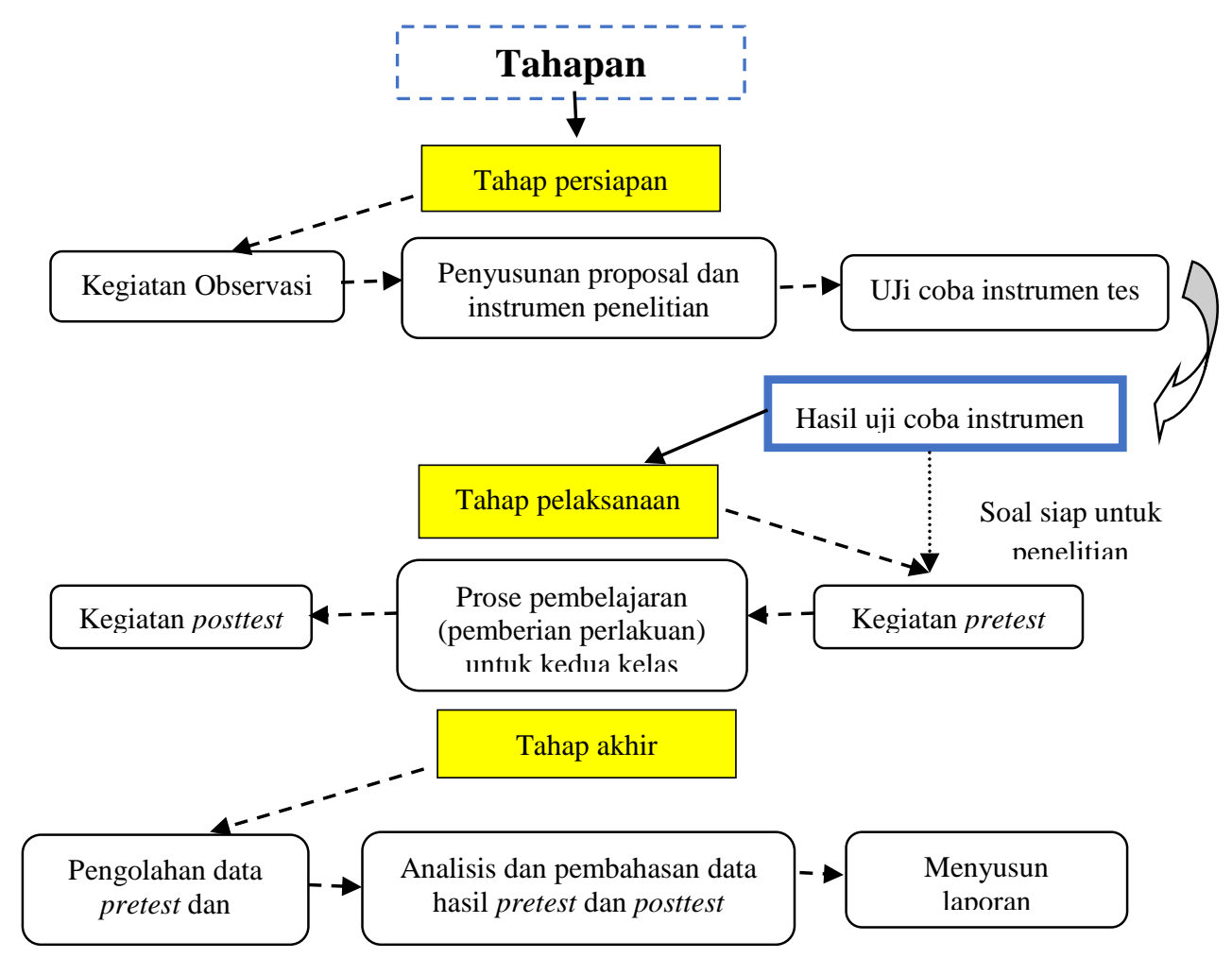

Bagan 1. Alur Tahapan Penelitian

Data penelitian ini berupa tes hasil belajar fisika. Pengumpulan data dilakukan dengan metode tes menggunakan tes pilihan ganda sebanyak 24 soal yang telah dipilih sesuai kriteria analisis uji instrumen. Tes dilakukan sebanyak dua kali yakni tes awal (pretest) dan tes akhir (posttest). Pretest dilakukan sebelum diberi perlakuan untuk mengetahui kemampuan awal siswa terhadap materi pelajaran. Sedangkan, posttest dimaksudkan untuk mengetahui hasil belajar siswa terhadap materi pelajaran setelah diberi perlakuan. Sebelum tes hasil belajar digunakan dalam penelitian, terlebih dahulu dilakukan uji coba instrumen dan analisis untuk mengetahui validitas, reliabilitas, daya beda dan kesukaran butir soal.

Analisis validitas soal menggunakan rumus product moment, uji realibilitas soal menggunakan rumus Spearman-Brown, indeks kesukaran soal untuk tingkat kesukaran soal dan indeks diskriminasi untuk daya beda soal. Analisis data menggunakan statistik parametrik t-test polled varians dengan kriteria uji dua pihak, yang sebelumnya telah diuji uji homogenitas (untuk mengetahui homogenitas sampel), uji normalitas (untuk mengetahui normalitas sampel). Sedangkan untuk mengetahui seberapa besar peningkatan akibat perlakuan model pembelajaran berbasis masalah dengan metode eksperimen terhadap hasil belajar fisika siswa digunakan uji N-Gain.

\section{HaSil dan PEMBahasan}

Hasil penelitian berupa deskripsi data hasil belajar fisika dari pretest dan posttest dengan menggunakan uji homogenitas, uji normalitas dan uji hipotesis (ttest polled varians). Adapun hasil rekapitulasi data pretest pada kelas eksperimen dan kelas kontrol pada materi cahaya dapat dilihat pada Tabel 2 berikut ini:

Tabel 2. Rekapitulasi Data Pretest Kelas Eksperimen dan Kelas Kontrol

\begin{tabular}{lcc}
\hline \multicolumn{1}{c}{ Komponen } & $\begin{array}{c}\text { Data Hasil Belajar Fisika } \\
\text { Siswa } \\
\text { Kelas } \\
\text { Eksperimen }\end{array}$ & $\begin{array}{c}\text { Kelas } \\
\text { Kontrol }\end{array}$ \\
\hline Jumlah siswa & 21 & 22 \\
Nilai tertinggi & 42 & 54 \\
Nilai terendah & 13 & 21 \\
Rata-rata & 27,38 & 35,41 \\
Varians $\left(\mathrm{S}^{2}\right)$ & 66,15 & 95,87 \\
Uji & \multicolumn{2}{c}{ Homogen } \\
Homogenitas & \multicolumn{2}{c}{} \\
\hline
\end{tabular}


Berdasarkan Tabel 2, data yang diperoleh menunjukkan bahwa hasil pretest pada kelompok eksperimen dan kelompok kontrol tidak memiliki perbedaan (homogen) pada kemampuan awalnya sebelum diberikan perlakuan. Hal ini disebabkan karena sebelum pretest diberikan, siswa pada kelas eksperimen maupun kelas kontrol belum mendapatkan pembelajaran mengenai materi cahaya sehingga siswa belum memiliki pengetahuan mengenai materi tersebut. Siswa hanya mengandalkan pengetahuannya tentang materi fisika sebelumnya atau dari pengalamannya sehari-hari.

Kondisi siswa tersebut berdampak pada rendahnya nilai siswa yang diperoleh pada pretest. Hal ini didasarkan dari nilai rata-rata tes awal yang diperoleh pada kedua kelas baik kelas eksperimen dan kelas kontrol masing-masing sebesar 27,38 dan 35,41.

Selanjutnya kedua kelas diberikan perlakuan yang berbeda. Untuk kelas eksperimen berupa model pembelajaran berbasis masalah dengan metode eksperimen dan kelas kontrol berupa pembelajaran konvensional, kemudian keduanya diberikan posttest. Data hasil posttest pada kelas eksperimen dan kelas kontrol pada materi cahaya dapat dilihat pada Tabel 3 berikut ini:

Tabel 3. Rekapitulasi Data Posttest Kelas Eksperimen dan Kelas Kontrol

\begin{tabular}{lcc}
\hline \multirow{2}{*}{ Komponen } & \multicolumn{2}{c}{ Data Hasil Belajar } \\
& $\begin{array}{c}\text { Fisika Siswa } \\
\text { Kelas }\end{array}$ & $\begin{array}{c}\text { Kelas } \\
\text { Konsperimen } \\
\text { Kontrol }\end{array}$ \\
\hline Jumlah siswa & 21 & 22 \\
Nilai tertinggi & 92 & 92 \\
Nilai terendah & 54 & 38 \\
Rata-rata & 75,19 & 64,73 \\
Varians $\left(\mathrm{S}^{2}\right)$ & 105,36 & 95,87 \\
Uji Normalitas & Normal & Normal \\
Uji Homogenitas & \multicolumn{2}{c}{ Homogen } \\
Uji Hipotesis & \multicolumn{2}{c}{$t_{\text {hitung }}>t_{\text {tabel }}}$, \\
& $\mathrm{H}_{0}$ ditolak, $\mathrm{H}_{\mathrm{a}}$ diterima \\
\hline
\end{tabular}

Dalam Tabel 3 setelah kedua kelas diberikan posttest, terlihat bahwa terjadi peningkatan nilai ratarata siswa kedua kelas dari sebelum dan setelah diberikan perlakuan. Nilai rata-rata tes akhir pada kelas eksperimen sebesar 75,19 dan kelas kontrol sebesar 64,73 . Berdasarkan nilai rata-rata pada tes akhir tersebut terdapat perbedaan peningkatan hasil belajar fisika siswa antara kelas eksperimen dan kelas kontrol, dimana nilai rata-rata tes akhir pada kelas eksperimen lebih tinggi dibandingkan kelas kontrol. Kelas eksperimen mengalami peningkatan nilai ratarata sebesar 47,81 sedangkan kelas kontrol mengalami peningkatan sebesar 29,32.

Selanjutnya hasil posttest diuji hipotesis yang bertujuan untuk mengetahui adanya pengaruh model pembelajaran berbasis masalah dengan metode eksperimen terhadap hasil belajar siswa pada kelas eksperimen. Penentuan jenis uji hipotesis yang digunakan dalam penelitian ini tergantung pada data hasil tes akhir uji homogenitas dan normalitas kedua kelas serta jumlah siswa yang mengikuti tes akhir. Berdasarkan rekapitulasi data posttest pada Tabel 3, diperoleh bahwa kedua kelas homogen dan terdistribusi normal, maka statistik yang digunakan adalah statistik parametrik. Jumlah siswa yang mengikuti tes akhir pada kedua kelas tidak sama. Pada kelas eksperimen siswa yang mengikuti tes akhir berjumlah 21 siswa, sedangkan pada kelas kontrol berjumlah 22 siswa. Berdasarkan hasil tersebut, jenis uji hipotesis yang dapat digunakan, yakni uji-t polled varian. Setelah data dianalisis menggunakan t-test polled varians diperoleh hasil $t_{\text {hitung }}>t_{\text {tabel }}$, yaitu $t_{\text {hitung }}=2,71$ dan $t_{\text {tabel }}=$ 2,02 pada taraf signifikan $5 \%$ dengan $\mathrm{dk}=\mathrm{n}_{1}+$ $\mathrm{n}_{2}-2=21+22-2=41$. Sesuai dengan kriteria pengujian hipotesis jika $t_{\text {hitung }}>t_{\text {tabel }}$ maka $\mathrm{H} 0$ ditolak dan Ha diterima. Berdasarkan hasil tersebut, maka disimpulkan bahwa terdapat pengaruh model pembelajaran berbasis masalah dengan metode eksperimen pada materi cahaya terhadap hasil belajar fisika siswa kelas VIII SMP Negeri 2 Gunungsari tahun ajaran 2014/2015.

Untuk mengetahui seberapa besar peningkatan akibat perlakuan model pembelajaran berbasis masalah dengan metode eksperimen digunakan uji $\mathrm{N}$ Gain. Analisis nilai $\mathrm{N}$-Gain dilihat dari besar peningkatan kemampuan hasil belajar pada kelas eksperimen dan kelas kontrol setelah diberikan perlakuan. Perbandingan peningkatan hasil belajar fisika siswa kedua kelas dapat dilihat pada diagram berikut ini: 


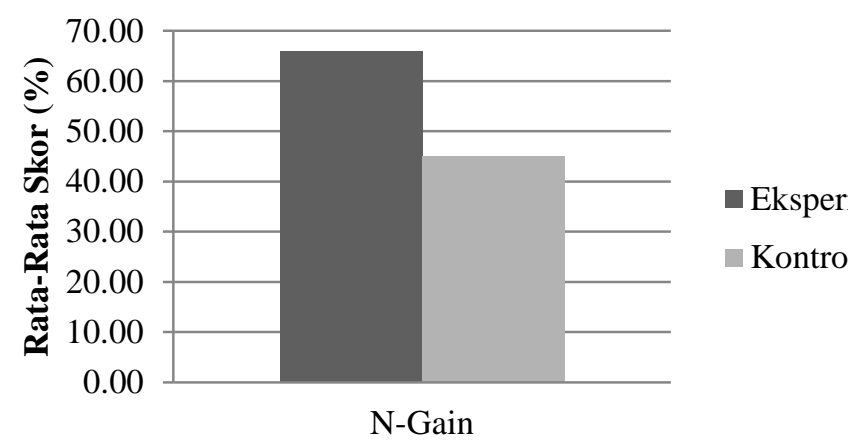

Gambar 1. Nilai Rata-Rata N-Gain Hasil Belajar

Fisika Siswa Kelas Eksperimen dan Kontrol

Diagram diatas menunjukkan bahwa nilai N-Gain pada kelas eksperimen lebih tinggi dari pada nilai $\mathrm{N}$ Gain pada kelas kontrol, dimana nilai N-Gain pada kelas eksperimen sebesar $66 \%$ dan pada kelas kontrol sebesar $45,07 \%$. Perhitungan nilai $\mathrm{N}-$ Gain juga dilakukan untuk mengetahui peningkatan pemahaman konsep fisika siswa per sub materi, yang dibagi menjadi tiga yaitu perambatan cahaya, pemantulan cahaya, dan pembiasan cahaya. Hasil perhitungan nilai $\mathrm{N}$-Gain per sub materi pada kelas eksperimen dan kontrol ditunjukkan pada diagram dibawah ini:

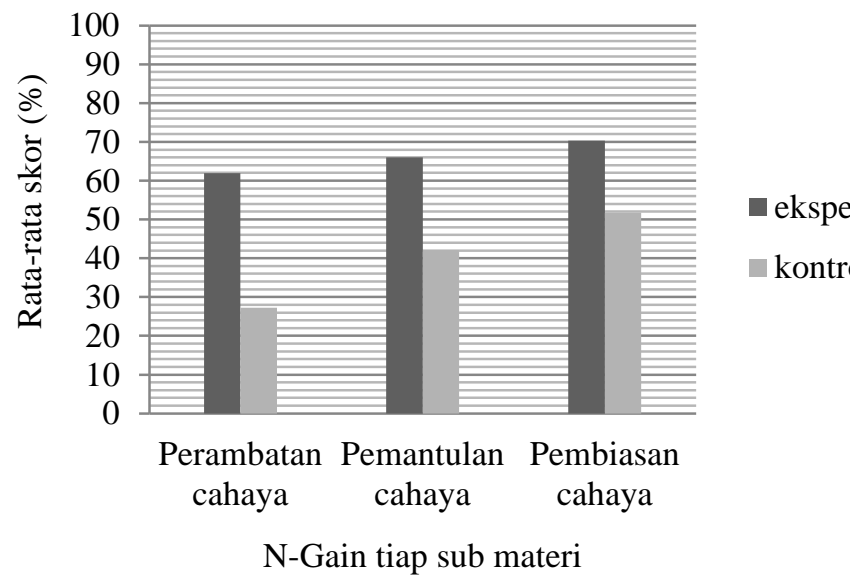

Gambar 2. Nilai Rata-Rata N-Gain Pemahaman Konsep Fisika Siswa Tiap Sub Materi

Cahaya Kelas Eksperimen dan Kontrol.

Secara keseluruhan, diagram diatas menunjukkan peningkatan pemahaman konsep fisika kelas eksperimen jauh lebih meningkat dibandingkan kelas kontrol pada semua sub materi cahaya. Perbedaan peningkatan keduanya dapat dipahami dari proses pembelajaran yang dilakukan. Pembelajaran konvensional selalu monoton berpusat pada guru dan siswa lebih banyak mendengar penyampaian materi saja. Siswa kesulitan bila diberikan soal-soal terkait materi yang diajarkan sehingga berdampak pada hasil belajar yang diperoleh. Berbeda dengan pembelajaran berbasis masalah yang memberikan pengalaman yang berbeda membuat siswa lebih senang dan aktif dalam pembelajaran, Model pembelajaran berbasis masalah dengan metode eksperimen membuat siswa lebih mudah menjawab soal-soal yang diberikan atau materi yang diajarkan. Sehingga, pembelajaran berbasis masalah dengan metode eksperimen lebih meningkatkan kemampuan kognitif siswa daripada pembelajaran konvensional

Model pembelajaran berbasis masalah mampu mengkonstruksi pengetahuan dan mengembangkannya berdasarkan pengalaman yang mereka terima dalam proses belajar di sekolah dan dalam kehidupan sehari-hari. Hal tersebut sesuai dengan pendapat Suprijono [5] bahwa model pembelajaran berbasis masalah mendorong siswa berusaha belajar dalam memecahkan masalah dengan mengembangkan kemampuan menganalisis dan mengelola informasi berdasarkan pengalaman yang telah dimiliki ataupun pengalaman baru yang dihadapi siswa itu sendiri. Contoh-contoh penerapan materi yang diberikan merupakan pengalaman seharihari yang sering diamati oleh siswa. Sehingga, memberikan keleluasaan siswa untuk mengembangkan pengetahuan barunya dalam memahami masalah di kehidupan nyata.

Model pembelajaran berbasis masalah dilakukan dengan adanya pemberian rangsangan berupa masalah-masalah yang kemudian dilakukan pemecahan masalah oleh siswa yang dapat menambah keterampilan siswa dalam pencapaian materi pembelajaran [6]. Hal ini sesuai hasil penelitian yang didapat bahwa model pembelajaran berbasis masalah selain dapat meningkatkan pemahaman konsep, juga mampu membuat siswa lebih aktif dalam pembelajaran dan menambah keterampilan siswa. Hal tersebut ditunjang dari data hasil pengamatan afektif dan psikomotorik siswa untuk kedua kelas pada diagram berikut ini: 

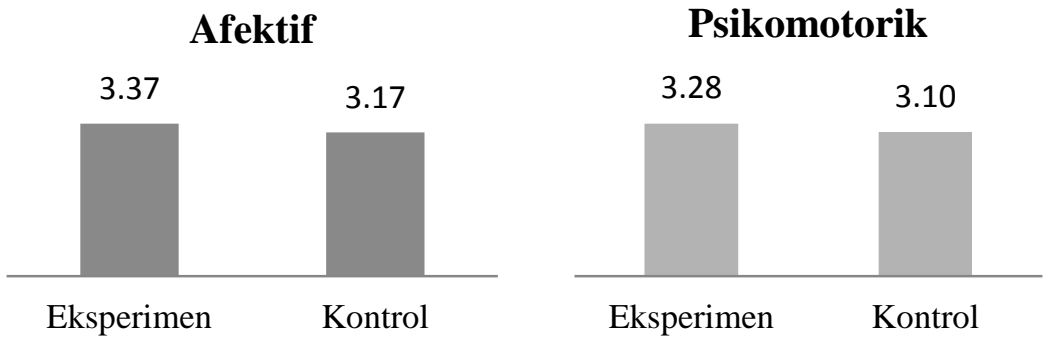

(a)

Gambar 3. Perbandingan nilai rata-rata hasil pengamatan (a) afektif dan (b) psikomotorik kelas eksperimen dan kontrol.

Dilihat dari diagram diatas bahwa kelas eksperimen yang diberi perlakuan dengan model pembelajaran berbasis masalah dengan metode eksperimen memiliki kemampuan psikomotorik dan afektif yang lebih baik daripada kelas kontrol. Oleh karena itu, model pembelajaran berbasis masalah dengan metode eksperimen ini sangat membantu siswa dalam mengembangkan pengetahuan dan keterampilan yang telah mereka pelajari serta membuat siswa lebih aktif dalam proses pembelajaran.

\section{UCAPAN TERIMA KASIH}

Terima kasih yang sebesar-besarnya penulis sampaikan kepada Bapak Dr.H.Wildan, M.Pd., Bapak Dr.Karnan, M.Si., Bapak Dr.Ahmad Harjono, S.Si., M.Si., Bapak Dr.rer.nat.Kosim, M.Si., Bapak Syahrial A. S.Pd., M.Si., Bapak Dr.Gunawan, M.Pd., serta semua pihak yang telah membantu penelitian ini.

\section{REFERENSI}

[1] Smith.P.L \& ragan.T.L.2003. Instructional Design.upper Saddle River, NJ. Merril Prentice Hall Inc.

[2] Trianto. 2010. Model Pembelajaran Terpadu Konsep, Strategi, dan Implementasinya Dalam Kurikulum Tingkat Satuan Pendidikan (KTSP). Jakarta: PT Bumi Aksara.

[3] Abidin, Y. 2014. Desain Sistem Pembelajaran dalam Konteks Kurikulum 2013. Bandung: PT Refika Aditama.

[4] Suyadi. 2013. Strategi Pembelajaran Pendidikan Berkarakter. Bandung: PT Remaja Rosdakarya.

\section{Penutur}

Berdasarkan rumusan masalah, hasil penelitian, dan pembahasan, maka disimpulkan bahwa model pembelajaran berbasis masalah dengan metode eksperimen pada materi cahaya berpengaruh terhadap hasil belajar fisika pada siswa kelas VIII SMPN 2 Gunungsari tahun ajaran 2014/2015. Pembelajaran berupa model pembelajaran berbasis masalah dengan metode eksperimen lebih meningkatkan kemampuan kognitif siswa daripada pembelajaran konvensional.

[5] Sugiyono. 2012. Statistik untuk Penelitian. Bandung: Alfabeta.

[6] Suprijono, A. 2009. Cooperative Learrning. Surabaya: Pustaka Pelajar.

[7] Kosasih, E. 2013. Strategi Belajar dan Pembelajaran Implementasi Kurikulum 2013. Bandung: Yrama Widya.

\section{Biografi Penulis}

Ardian Firmansyah, lahir di Surabaya, tepatnya pada tanggal 22 April 1993. Penulis menyelesaikan bangku pendidikan di SDN Inpres 51 Kota Bima tahun 2005, SMPN 15 Mataram tahun 2008, dan SMAN 5 Mataram tahun 2010. Penulis kemudian melanjutkan studinya di Universitas Mataram, Fakultas Keguruan dan Ilmu Pendidikan, Program Studi Pendidikan Fisika dan lulus pada tahun 2015. 